\title{
Comparison of Efficacy and Complications of Holmium Laser and Pneumatic Lithotripters Used in the Ureterorenoscopic Treatment of Proximal Ureter Stones, a Multi-Center Study of Society of Urological Surgery Aegean Study Group
}

\author{
Proksimal Üreter Taşlarının Üreterorenoskopi ile Tedavisinde Kullanılan Holmiyum Lazer ve \\ Pnömatik Litotriptörlerin Etkinlik ve Komplikasyonlarının Karşılaştııılması, Ürolojik Cerrahi \\ Derneği Ege Çalışma Grubu'nun Çok Merkezli Bir Çalışması
} \begin{abstract}
(D) Mehmet Şahin ${ }^{8}$, (D) Mehmet Oğuz Şahin², (D) 0ktay Üçer ${ }^{3}$, (D) Fuat Kızılay ${ }^{8}$, (D) Ozan Bozkurt ${ }^{4}$
'İzmir Metropolitan Municipality Eşrefpaşa Hospital, Clinic of Urology, Izmir, Turkiye

${ }^{2}$ Manisa State Hospital, Clinic of Urology, Manisa, Turkiye

${ }^{3}$ Manisa Celal Bayar University Faculty of Medicine, Department of Urology, Manisa, Turkiye

${ }^{4}$ Dokuz Eylül University Faculty of Medicine, Department of Urology, Izmir, Turkiye

${ }^{5}$ Istanbul Bahçelievler State Hospital, Clinic of Urology, Izmir, Turkiye

${ }^{6}$ Bülent Ecevit University Faculty of Medicine, Department of Urology, Zonguldak, Turkiye

${ }^{7}$ Niğde Ömer Halisdemir University Faculty of Medicine, Department of Urology, Niğde, Turkiye

${ }^{8}$ Ege University Faculty of Medicine, Department of Urology, İmir, Turkiye
\end{abstract}

(D) Bora İrer ${ }^{1}$, (D) Volkan Şen², (D) Oğuzcan Erbatu ${ }^{3}$, (D) Alperen Yıldız , (D) Şakir Ongün ${ }^{5}$, (D) Önder Çınar ${ }^{6}$, (D) Ahmet Cihan ${ }^{7}$,

\section{What's known on the subject? and What does the study add?}

Turkiye is an endemic region for urinary system stone disease and the incidence rate is $14.8 \%$. Currently, ureterorenoscopy, where laser and pneumatic energy sources are used as lithotripter, is the first choice in the treatment of ureteral stones. The aim of this multi-centered study was to compare the efficacy of holmium laser and pneumatic lithotripters used in the ureterorenoscopic treatment of proximal ureteral stones and investigate their complications.

\begin{abstract}
Objective: The aim of this study is to compare the efficacy and complications of holmium laser and pneumatic lithotripsy used in the ureterorenoscopic treatment of proximal ureteral stones.

Materials and Methods: Data of 638 patients, who underwent ureterorenoscopy (URS) due to proximal ureteral stones in different centers, were obtained from patient files. The patients were divided into two groups according to the type of lithotripter used: group 1; laser lithotripter ( $\mathrm{n}=324$; $50.8 \%)$ and group 2 ; pneumatic lithotripter $(n=314 ; 49.2 \%)$. URS was considered successful upon determination stone-free status with the imaging methods after treatment. The effectiveness and the complications of holmium:yttrium-aluminum-garnet laser and pneumatic lithotripsy were compared.

Results: The total success rate of URS was $82.6 \%$ and the complication rate was $8.1 \%$. The mean age of patients was similar between the groups; however, the body mass index values, stone surface area and stone Hounsfield unit were significantly higher in group 1. Although the mean operative time, complication rate and the mean length of hospital stay were similar between the groups; the URS success and postoperative ureteral
\end{abstract}

Correspondence: Bora İrer MD, İzmir Metropolitan Municipality Eşrefpaşa Hospital, Clinic of Urology, İzmir, Turkiye E-mail: borairer@yahoo.com 0RCID-ID: orcid.org/0000-0002-7719-9033

Received: 19.06.2018 Accepted: 27.06.2018

Cite this article as: İrer B, Şen V, Erbatu O, Yıldız A, Ongün Ş, Çınar Ö, Cihan A, Şahin M, Şahin MO, Üçer O, Kızılay F, Bozkurt O. Comparison of Efficacy and Complications of Holmium Laser and Pneumatic Lithotripters Used in the Ureterorenoscopic Treatment of Proximal Ureter Stones, a Multi-Center Study of

Society of Urological Surgery Aegean Study Group. J Urol Surg 2018;5(3):158-163. 
J stent use rates were significantly higher in group 1 and the push-back rate was significantly higher in group 2.

Conclusion: If laser lithotripsy is available in a clinic, we believe that it is better to use it as the first option in the treatment of proximal ureter stones. However, considering that it is not easy to access laser lithotripters due to their high cost in Turkey, pneumatic lithotripters may be an effective and inexpensive alternative that can also be safely used in these cases.

Keywords: Complication, Laser lithotripter, Pneumatic lithotripter, Proximal ureter stone, Ureter stone

Öz

Amaç: Bu çalışmanın amacı proksimal üreter taşlarının üreterorenoskopi (URS) ile tedavisinde kullanılan holmiyum lazer ve pnömatik litotriptörlerin etkinlik ve komplikasyonlarını karşılaştırmaktır.

Gereç ve Yöntem: Proksimal üreter taşı nedeni ile farklı referans merkezlerde URS yapılan toplamda 638 hastanın verileri retrospektif olarak tarandı. Hastalar kullanılan litotriptör türüne göre 2 gruba ayrıldı: Grup 1; lazer litotriptör $(n=324 ; \% 50,8)$ ve grup 2; pnömatik litotriptör ( $n=314$; \%49,2). URS başarısı, tedavi sonrası yapılan görüntüleme tetkiklerinde taşsızlık saptanması olarak alındı. Holmium:yttrium-aluminum-garnet lazer ve pnömatik litotriptörlerin başarı ve komplikasyon oranları karşılaştırıldı.

Bulgular: Toplamda URS başarısı \%82,6 ve genel komplikasyon oranı ise \%8,1 idi. Lazer litotriptör kullanılan hastalarla pnömatik litotriptör kullanılan hastalar demografik veriler ve taş özelliklerine göre karşılaştırıldıklarında; her iki grubun yaş ortalamaları benzerdi ancak hastaların vücut kitle indeks değerleri, taş alanı ve Hounsfield ünitesi değerleri grup 1'de anlamlı olarak yüksek saptandı. Grup 1 hastalarında şok dalgasıyla böbrek taşı kırdırma öyküsü olanlar anlamlı olarak daha fazla saptandı. Her iki grup operasyon sonuçlarına göre ve komplikasyon oranlarına göre karşılaştırıldığında; operasyon süresi, komplikasyon oranları ve hastanede yatış süreleri açısından benzer olarak saptansa da URS başarısı ve postop üreteral J stent kullanımı grup 1'de anlamlı olarak yüksek; push back oranları ise grup 2'de anlamlı olarak yüksek saptandı. Her iki gruptaki komplikasyonlar ClavienDindo sınıflamasına göre karşılaştırıldığında anlamlı bir fark saptanmadı.

Sonuç: Eğer kliniklerde lazer litotiripsi mevcutsa, proksimal üreter taşları tedavisinde ilk seçenek litotriptör olarak kullanılmasının daha uygun olacağı kanısındayız. Ancak ülkemizde yüksek maliyetleri nedeni ile lazer litotriptörlere ulaşımın çok da kolay olmadığını düşünürsek; etkin ve ucuz bir yöntem olan pnömatik litotriptörler de güvenle bu olgularda kullanılabilir.

Anahtar Kelimeler: Komplikasyon, Lazer litotripsi, Pnömatik litotripsi, Proksimal üreter taşı, Üreter taşı

\section{Introduction}

The prevalence of urinary system stone disease has been reported to be $4-20 \%$ in economically developed countries $(1,2)$. The incidence of stone disease varies according to geographical, climatic, ethnic, racial, dietary and genetic factors $(3,4)$. In Turkey, it is an endemic disease with a rate of $14.8 \%$ (5).

Methods that can be used in the treatment of ureteral stones include conservative treatment-monitoring, medical expulsive therapy, extra-corporal shock wave lithotripsy (ESWL), and ureterorenoscopy (URS). If there is no indication for active stone removal, the first treatment option is either conservative monitoring or medical expulsive treatment. According to the European Association of Urology guidelines, if there is an indication for active stone removal (for stones that are not likely to pass spontaneously and in the presence of symptoms, such as persistent pain despite adequate analgesic treatment, persistent obstruction, and renal insufficiency), the first treatment choice for proximal ureteral stones is URS if the stone is larger than 10 $\mathrm{mm}$ and ESWL or URS if the stone size is less than $10 \mathrm{~mm}$ (6). Studies have shown that the success of URS is affected by the size, location, number and composition of the stone, whether it is impacted, and the lithotripter that is used $(7,8)$. With the development of technology, various energy sources, including ultrasonic, pneumatic, electrohydraulic and laser lithotripters have begun to be used for stone fragmentation $(9,10)$. Currently, the most common ones are pneumatic and laser lithotripters, both have certain advantages and disadvantages (11). In this study, we aimed to compare the efficacy of holmium laser and pneumatic lithotripsy used in URS for proximal ureteral stones and to investigate their complications according to the ClavienDindo classification.

\section{Materials and Methods}

\section{Patients and Data Collection}

A total of eight centers were included in the study. Data of patients, who underwent URS due to proximal ureteral stones in different reference centers, were obtained from patient files. A total of 638 patients underwent ureteroscopic lithotripsy. The patients were divided into two groups according to the type of lithotripter: group 1 ; laser lithotripter $(n=324 ; 50.8 \%)$ and group 2 ; pneumatic lithotripter $(n=314 ; 49.2 \%)$. Stones located in the region between the ureteropelvic junction and the pelvic brim in the ureter were accepted as proximal stones and included in the study. The stones that were immobilized, embedded in the ureteric mucosa, and had mucosa-folded on them during the endoscopic visualization, were evaluated as impacted stones. URS was considered successful upon determination stone-free status with the imaging methods after treatment. All patients were evaluated postoperatively by non-contrast computed tomography or abdominal radiography. Stone surface area is calculated by multiplying the stone length by stone witdh in $\mathrm{mm}$. Data on patients' perioperative double J stent requirement, gender, stone push-back status, general complication rate and Clavien-Dindo grade and URS success rate (stone-free) 
were collected. The effectiveness and the complications of holmium:yttrium-aluminum-garnet (YAG) laser and pneumatic lithothripsy were compared.

This study was conducted retrospectively and approved by the Ethics Committee of Dokuz Eylül University with number 2018/03-03. Written informed consent was not obtained from patients.

\section{Surgical Technique}

Sterile urine culture was provided prior to the procedure. Cefazolin (1 g IV) was administered following spinal or general anesthesia. The choice of anesthesia type was mostly determined by the preference of anesthetists in the centers participating in the study. In the lithotomy position, 5\% lidocaine gel was applied to the urethra. All the procedures were performed by semirigid ureteroscopes with an 8 or $9 \mathrm{Fr}$ distal tip. A guidewire with $3 \mathrm{~cm}$ flexible tip was used routinely to guide ureteroscope. If stone access was achieved, a holmium laser or a pneumatic lithotripter was used for stone fragmentation. Lithotripter selection was made according to the facilities in the centers participating in the study. A 16 or 18 Fr Foley catheter was introduced into the bladder with the completion of the operation and was withdrawn on the same day or one day later.

\section{Statistical Analysis}

Pearson's chi-square test was used to compare the difference in types of anesthesia method between the two groups. If the smallest theoretical frequency was $<5$, the Fisher's exact test was used to analyze the variables. An independent-samples t-test was conducted to compare outcomes for URS with holmium:YAG laser and pneumatic lithothripsy. Data were analyzed using the SPSS (version 23.0) statistical program. A p value of less than 0.05 was considered statistically significant.

\section{Results}

Of the 638 patients included in the study, 424 (66.5\%) were male and 214 (33.5\%) were female. The mean age was $44.9 \pm 14.4$ years, and 208 patients (32.6\%) had co-morbidities, of whom $188(29.5 \%)$ were undergoing medical treatment. Approximately half the patients had a history of stone passing ( $n=304,47.6 \%)$. Among these patients, 183 (28.7\%) had previously undergone ESWL and $98(15.4 \%)$ had a history of stone surgery. The operation was performed under general anesthesia in 329 patients (51.6\%) and spinal anesthesia in 309 (48.4\%). The mean duration of the operation was calculated as $45.1 \pm 19.1$ $\mathrm{min}$. There was no residual stone in 527 patients $(82.6 \%)$, and the complication rate was $8.1 \%(n=52)$. Table 1 presents the demographic data of the patients, general characteristics of the stones and detailed information about the operations.
When the laser lithotripter group (group $1 ; n=324,50.8 \%$ ) and the pneumatic lithotripter group (group $2 ; n=314,49.2 \%$ ) were compared in terms of demographics and stone characteristics, it was found that the mean ages were similar $(44.5 \pm 13.2$ vs $45.2 \pm 15.5$, respectively, $p=0.542$ ), but the mean body mass

Table 1. Demographic data and stone characteristics of the patients

\begin{tabular}{|c|c|}
\hline Age $($ mean $\pm \mathrm{SD})$ & $44.88 \pm 14.41$ \\
\hline $\mathrm{BMI}\left(\mathrm{kg} / \mathrm{m}^{2}\right)($ mean $\pm \mathrm{SD})$ & $26.2 \pm 3.5$ \\
\hline Stone area $\left(\mathrm{mm}^{2}\right)($ mean $\pm \mathrm{SD})$ & $83.7 \pm 57.2$ \\
\hline Hounsfield unit (mean \pm SD) & $883.7 \pm 380.4$ \\
\hline Operation time (minutes) (mean \pm SD) & $45.13 \pm 19.13$ \\
\hline \multirow[t]{2}{*}{ Hospitalization time (days) (mean \pm SD) } & $1.78 \pm 2.00$ \\
\hline & $\mathrm{n}, \%$ \\
\hline \multicolumn{2}{|l|}{ Gender } \\
\hline Male & $424(66.5 \%)$ \\
\hline Female & $214(33.5 \%)$ \\
\hline \multicolumn{2}{|l|}{ Comorbidity } \\
\hline Yes & $208(32.6 \%)$ \\
\hline No & $430(67.4 \%)$ \\
\hline \multicolumn{2}{|l|}{ Medication } \\
\hline Yes & $188(29.5 \%)$ \\
\hline No & $450(70.5 \%)$ \\
\hline \multicolumn{2}{|l|}{ Previous stone disease history } \\
\hline Yes & $304(47.6 \%)$ \\
\hline No & $334(52.4 \%)$ \\
\hline \multicolumn{2}{|l|}{ Previous ESWL history } \\
\hline Yes & $183(28.7 \%)$ \\
\hline No & $455(71.3 \%)$ \\
\hline \multicolumn{2}{|l|}{ Stone side } \\
\hline Left & $324(50.8 \%)$ \\
\hline Right & $314(49.2 \%)$ \\
\hline \multicolumn{2}{|l|}{ Lithotriptor } \\
\hline Laser & $324(50.8 \%)$ \\
\hline Pneumothic & $314(49.2 \%)$ \\
\hline \multicolumn{2}{|l|}{ Anesthesia } \\
\hline Spinal & $309(48.4 \%)$ \\
\hline General & $329(51.6 \%)$ \\
\hline \multicolumn{2}{|l|}{ Ureteral J stent } \\
\hline Yes & $396(62.1 \%)$ \\
\hline No & $242(37.9 \%)$ \\
\hline \multicolumn{2}{|l|}{ Complication } \\
\hline Yes & $52(8.1 \%)$ \\
\hline No & $568(89.0 \%)$ \\
\hline \multicolumn{2}{|l|}{ Ureteroscopy } \\
\hline Successful & $527(82.6 \%)$ \\
\hline Unsuccessful & $111(17.4 \%)$ \\
\hline \multicolumn{2}{|c|}{$\begin{array}{l}\text { SD: Standard deviation, BMI: Body mass index, ESWL: Extra-corporal shock wave } \\
\text { lithotripsy }\end{array}$} \\
\hline
\end{tabular}


index values, stone surface area and Hounsfield unit (HU) values were significantly higher in group 1 than in group $2(26.9 \pm 3.4$ vs $25.7 \pm 3.6, p<0.001 ; 90.7 \pm 64.4$ vs $76.4 \pm 47.6, p=0.002$; and $973.7 \pm 410.2$ vs $814.3 \pm 340.6, p<0.001$, respectively). The number of patients with a history of ESWL and number of operations performed under general anesthesia in group 1 was higher than in group 2 (33\% vs $24.2 \%, p=0.014$ and $68.2 \%$ vs $34.4 \%$, $\mathrm{p}<0.001$, respectively). In group 2, co-morbidities were more common (25.9\% for group 1 and 39.5\% for group 2, $\mathrm{p}<0.001)$, and a higher number of operations were performed under spinal anesthesia (31.8\% for group 1 and $65.6 \%$ for group $2, p<0.001$ ) (Table 2).

When the two groups were compared for surgical outcomes and complication rates; the results were similar in terms

Table 2. Relationship of demographic data and stone characteristics with the lithotripter type

\begin{tabular}{|c|c|c|c|}
\hline & $\begin{array}{l}\text { Group } 1 \\
\text { (laser) } \\
n=324\end{array}$ & $\begin{array}{l}\text { Group } 2 \\
\text { (pneumatic) } \\
n=314\end{array}$ & $\mathbf{p}$ \\
\hline Age (years) & $44.5 \pm 13.3$ & $45.2 \pm 15.5$ & 0.542 \\
\hline BMI $\left(\mathrm{kg} / \mathrm{m}^{2}\right)$ & $26.9 \pm 3.4$ & $25.7 \pm 3.6$ & $<0.001$ \\
\hline Stone area $\left(\mathrm{mm}^{2}\right)$ & $90.7 \pm 64.4$ & $76.4 \pm 47.6$ & 0.002 \\
\hline Hounsfield unit & $973.7 \pm 410.2$ & $814.3 \pm 340.6$ & $<0.001$ \\
\hline \multicolumn{4}{|l|}{ Gender } \\
\hline Male & $226(69.8 \%)$ & $198(63.1 \%)$ & \\
\hline Female & $98(30.2 \%)$ & 116 (36.9\%) & 0.079 \\
\hline \multicolumn{4}{|l|}{ Co-morbidity } \\
\hline Yes & $84(25.9 \%)$ & $124(39.5 \%)$ & \\
\hline No & $240(74.1 \%)$ & $190(60.5 \%)$ & $<0.001$ \\
\hline \multicolumn{4}{|l|}{ Type of anesthesia } \\
\hline Spinal & $103(31.8 \%)$ & $206(65.6 \%)$ & \\
\hline General & $221(68.2 \%)$ & $108(34.4 \%)$ & $<0.001$ \\
\hline \multicolumn{4}{|l|}{ Stone side } \\
\hline Right & $160(49.4 \%)$ & $164(52.2 \%)$ & \\
\hline Left & $164(50.6 \%)$ & $150(47.8 \%)$ & 0.261 \\
\hline \multicolumn{4}{|c|}{$\begin{array}{l}\text { Previous stone disease } \\
\text { history }\end{array}$} \\
\hline Yes & $152(46.9 \%)$ & $162(51.6 \%)$ & \\
\hline No & $172(53.1 \%)$ & $152(48.4 \%)$ & 0.383 \\
\hline \multicolumn{4}{|c|}{ Previous ESWL history } \\
\hline Yes & $107(33 \%)$ & $76(24.2 \%)$ & \\
\hline No & $217(67 \%)$ & $238(75.8 \%)$ & 0.014 \\
\hline \multicolumn{4}{|l|}{$\begin{array}{l}\text { Previous stone } \\
\text { operation history }\end{array}$} \\
\hline Yes & $53(16.4 \%)$ & 45 (14.3\%) & \\
\hline No & $271(84.6 \%)$ & $269(85.7 \%)$ & 0.478 \\
\hline
\end{tabular}

of duration of operation, complication rates and length of hospital stay $(44.7 \pm 20.7 \mathrm{~min}$ vs $45.6 \pm 17.3 \mathrm{~min}, \mathrm{p}=0.533 ; 7.7 \%$ vs $8.6 \%, p=0.396$; and $1.8 \pm 1.0$ days vs $1.8 \pm 2.7$ days, $p=0.864$, respectively), the URS success and postoperative ureteral J stent use were significantly higher in group 1 than in group $2(89.8 \%$ vs $75.2 \%, p<0.001$ and $75.9 \%$ vs $47.8 \%, p<0.001$, respectively), whereas the push back rate was significantly higher in group 2 $(3.5 \%)$ compared to group $1(1.2 \%)(p<0.001)$ (Table 3$)$.

There was no significant difference between the two groups in the rate of complication according to the Clavien-Dindo classification $(p=0.525)$. The most common complication was postoperative fever $(n=24,3.8 \%)$, followed by lumbar pain $(n=11,1.7 \%)$, urosepsis $(n=5,0.8 \%)$, ureteral perforation $(n=5,0.8 \%)$, urinary tract infection $(n=5,0.8 \%)$, postoperative hematuria $(n=1,0.2 \%)$, and arrhythmia $(n=1,0.2 \%)$.

\section{Discussion}

Although ESWL has been used as the first option for the treatment of proximal ureteral stones, with the recent developments in ureterorenoscopes leading to the reduction in their diameter and the emergence of flexible devices, URS has become the first treatment choice, in particular for stones

Table 3. The effect of lithotripter type on operation outcomes

\begin{tabular}{|c|c|c|c|}
\hline & $\begin{array}{l}\text { Group } 1 \\
\text { (laser) } \\
n=324\end{array}$ & $\begin{array}{l}\text { Group } 2 \\
\text { (pneumatic) } \\
n=314\end{array}$ & $\mathbf{p}$ \\
\hline Operation time (minute) & $44.7 \pm 20.7$ & $45.6 \pm 17.3$ & 0.533 \\
\hline \multicolumn{4}{|l|}{ Double $\mathrm{j}$ stent } \\
\hline Positive & $246(75.9 \%)$ & $150(47.8 \%)$ & \\
\hline Negative & $78(24.1 \%)$ & $184(52.2 \%)$ & $<0.001$ \\
\hline \multicolumn{4}{|l|}{$\begin{array}{l}\text { Push-back to the } \\
\text { collecting system }\end{array}$} \\
\hline Positive & $4(1.2 \%)$ & $11(3.5 \%)$ & \\
\hline Negative & $320(98.8 \%)$ & 303 (97.6\%) & 0.050 \\
\hline \multicolumn{4}{|l|}{ Complication } \\
\hline Positive & $25(7.7 \%)$ & $27(8.6 \%)$ & \\
\hline Negative & $299(92.3 \%)$ & $287(91.4 \%)$ & 0.396 \\
\hline \multicolumn{4}{|l|}{ Clavien classification } \\
\hline Clavien 1 & $20(6.2 \%)$ & $16(5.1 \%)$ & \\
\hline Clavien 2 & $2(0.6 \%)$ & $4(1.3 \%)$ & \\
\hline Clavien 3 & $2(0.6 \%)$ & $3(1.0 \%)$ & \\
\hline Clavien 4 & $1(0.3 \%)$ & $4(1.3 \%)$ & \\
\hline Negative & $299(92.3 \%)$ & $304(91.4 \%)$ & 0.525 \\
\hline Length of stay (day) & $1.8 \pm 1.0$ & $1.8 \pm 2.7$ & 0.864 \\
\hline \multicolumn{4}{|l|}{$\begin{array}{l}\text { Ureteroscopy success } \\
\text { rate }\end{array}$} \\
\hline Successful & $291(89.8 \%)$ & $236(75.2 \%)$ & \\
\hline Unsuccessful & $33(10.2 \%)$ & $78(24.8 \%)$ & $<0.001$ \\
\hline
\end{tabular}


$>10 \mathrm{~mm}$ (6). The technical improvement of lithotripters used predominantly for stone fragmentation has led to an increase in the URS success rates and decrease in the complication rates $(7,12)$. Today, the most commonly used devices are laser and pneumatic lithotripters.

Laser lithotripters first came into use in the late 1980s with dyelaser technology $(13,14)$. Recently, a very commonly preferred technique is holmium laser, which is capable of performing fragmentation by providing energy through small-diameter quartz fibers that can pass through the working channels of the smallest ureterorenoscopes (15). Holmium:YAG laser is able to fragment all types of stones, including hard calcium oxalate monohydrate and cystine stones, and can perform stone breaking with an ablative effect and dusting. The success rates of laser lithotripsy, which has been widely used in the treatment of proximal ureteral stones, have been reported to be 81.8-90.9\% $(7,15,16)$. In the current study, the success of URS in patients with proximal ureter stones who underwent laser lithotripsy was found to be $89.8 \%$, consistent with the literature.

Pneumatic lithotripters, which began to be manufactured in the early 1990s, are the most preferred devices in current medical practice in Turkey due to having the lowest cost and successful treatment outcomes (17). The working principle of a pneumatic lithotripter is that the metal probe passing through the straight endoscopic channel within the ureteroscope and directly contacting the stone is driven forward with a projectile created by means of the air pressure generated by the pneumatic lithotripter, and as a result of the applied force, the stone is fragmented. The success rates of pneumatic lithotripters in the treatment of proximal ureteral stones have been reported to vary between $75 \%$ and $90.5 \%(12,18,19,20)$. Similarly, in the current study, this rate was found to be $75.2 \%$. In this study, we found that laser lithotripsy had a higher success rate for the treatment of proximal ureteral stones than pneumatic lithotripsy (89.8\% and $75.2 \%$, respectively). The most important reason for this is the significantly higher rate of push-back observed in pneumatic lithotripsy (3.5\%) compared to laser lithotripsy (1.2\%). In a study conducted with 100 patients, Tipu et al. (21) reported push-back rates of $16 \%$ and $4 \%$ in pneumatic and laser lithotripsy, respectively. In a retrospective study of 1.296 patients who underwent pneumatic lithotripsy, the push-back rate for proximal ureteral stones was found to be $1.6 \%$ (12). In a randomized controlled trial, Razzaghi et al. (22) reported a push-back rate of $17.9 \%$ in the pneumatic group and no push-back in the laser group after evaluating 56 patients in each group. These varying push-back rates in the literature may be due to the different number of patients and the operations being performed by different surgeons.

In URS, the complication rates range from $9 \%$ to $25 \%$, and the majority are minor complications that do not require any intervention (23). Some studies in the literature have also compared complications according to the type of lithotripter used for the treatment of proximal ureteral stones. Bapat et al. (8) and Tipu et al. (21) reported a significantly lower complication rate in patients undergoing laser lithotripsy, whereas Kassem et al. (18) and Aydemir et al. (20) did not find any significant difference between the two groups in terms of complications. In the current study, we did not observe any significant difference in the rate of complication according to the Clavien-Dindo classification between patients who underwent laser lithotripsy and those underwent pneumatic lithotripsy.

Despite the higher URS success rate in the laser lithotripsy group in our study, the use of ureteral J stent was also significantly higher in this group. This may be due to the significantly higher parameters of preoperative history of ESWL, stone area and stone $\mathrm{HU}$ in the laser lithotripsy group compared to the pneumatic lithotripsy group. Strohmaier et al. (24) pointed that lower URS success rates in patients with a preoperative history of ESWL might be a result of mucosal edema that primarily occurred following ESWL. Similarly, in a study investigating the significance of stone size in the treatment of distal ureteral stones, Tuğcu et al. (25) reported that in patients with a preoperative history of ESWL, the URS operation was more difficult due to mucosal edema and the stones having become impacted. In the same study, it was found that as the size of ureteral stones increased, the complications increased but there was no statistically significant difference. In their study including 154 patients, Taş et al. (26) investigated the incidence of ureteral stenosis in patients undergoing pneumatic lithotripsy for the treatment of distal ureteral stones and found high rates of ureteral $\mathrm{J}$ stent implantation associated with increased mucosal edema, ureteral perforation, and high stone burden. In a recently published study, it was also reported that in patients who underwent flexible URS, the high values of stone $\mathrm{HU}$ prolonged the operative time and were associated with residual stone fragments (27). As the $\mathrm{HU}$ value indicating stone fragility increases, fragmentation of the stone may become more difficult, increasing the possibility of residual stones and requirement of ureteral J stent placement.

\section{Study Limitations}

Our study has some limitations, such as having a retrospective and multi-center design. For this reason, a complete standardization of surgical (different surgeons and ureterorenoscopes) and anesthetic (different anesthetist) applications have not been achieved.

\section{Conclusion}

In the treatment of proximal ureter stones, the success rates of laser lithotripsy were found to be higher than those of pneumatic lithotripsy, while the complication rates were similar. If laser lithotripsy is available in a clinic, we believe that it is 
better to use it as the first option in the treatment of proximal ureter stones. However, considering that it is not easy to access laser lithotripters due to their high cost in Turkey, pneumatic lithotripters may be an effective and inexpensive alternative that can also be safely used in these cases.

\section{Ethics}

Ethics Committee Approval: This study was approved by the Ethics Committee of Dokuz Eylül University with number 2018/03-03.

Informed Consent: Written informed consent was not obtained from patients because this was a retrospective study.

Peer-review: Externally and internally peer-reviewed.

\section{Authorship Contributions}

Surgical and Medical Practices: B.I.., V.Ş., O.E., A.Y., S..O., Ö.Ç., A.C., M.Ş., M.O.Ş., O.Ü, F.K., O.B., Concept: B.I.., V.Ş., M.O.Ş., O.Ü., F.K., O.B., Design: B.I., V.Ş., M.O.Ş., O.Ü., F.K., O.B., Data Collection or Processing: B.I., V.Ş., O.E., A.Y., S..O., Ö.Ç., A.C., M.Ş., M.O.Ş., O.Ü., F.K., O.B., Analysis or Interpretation: B.I., Literature Search: V.Ş., Writing: B.i., V.Ş.

Conflict of Interest: No conflict of interest was declared by the authors.

Financial Disclosure: The authors declared that this study received no financial support.

\section{References}

1. Trinchieri A. Epidemiology of urolithiasis. Arch Ital Urol Androl 1996;68:203250.

2. Kim HH, Jo MK, Kwak C, Park SK, Yoo KY, Kang D, Lee C. Prevalence and epidemiologic characteristics of urolithiasis in Seoul, Korea. Urology 2002;59:517-521.

3. Soueidan $M$, Bartlett SJ, Noureldin YA, Andersen RE, Andonian S. Leisure time physical activity, smoking and risk of recent symptomatic urolithiasis: survey of stone clinic patients. Can Urol Assoc J 2015;9:257-262.

4. Ordon M, Urbach D, Mamdani M, Saskin R, Honey RJ, Pace KT. A population based study of the changing demographics of patients undergoing definitive treatment for kidney stone disease. J Urol 2015;193:869-874.

5. Akinci M, Esen T, Tellaloğlu S. Urinary stone disease in Turkey: an updated epidemiological study. Eur Urol 1991;20:200-203.

6. Zumstein V, Betschart P, Abt D, Schmid HP, Panje CM, Putora PM. Surgical management of urolithiasis - a systematic analysis of available guidelines. BMC Urol 2018;18:25.

7. Degirmenci T, Gunlusoy B, Kozacioglu Z, Arslan M, Koras O, Arslan B, Minareci S. Comparison of Ho: YAG laser and pneumatic lithotripsy in the treatment of impacted ureteral stones: an analysis of risk factors. Kaohsiung J Med Sci 2014;30:153-158.

8. Bapat SS, Pai KV, Purnapatre SS, Yadav PB, Padye AS. Comparison of holmium laser and pneumatic lithotripsy in managing upper-- ureteral stones. J Endourol 2007;21:1425-1427.

9. Torricelli FC, Mazzucchi E, Danilovic A, Coelho RF, Srougi M. Surgical management of bladder stones: literature review. Rev Col Bras Cir 2013:40:227-233.
10. Barr JD, Tegtmeyer CJ, Jenkins AD. In situ lithotripsy of ure $\neg$ teral calculi: review of 261 cases. Radiology 1990;174:103-108.

11. Yüksel MB, Çelen I, Özbek E, Gümüş B. Cost-effective analysis of pneumatic and laser lithotripsy techniques in ureteral Stones. Dicle Medical Journal 2013;40:75-80.

12. Gunlusoy B, Degirmenci T, Arslan M, Kozacioglu Z, Nergiz N, Minareci S, Ayder AR. Ureteroscopic pneumatic lithotripsy: is the location of the stone important in deci-sion making? Analysis of 1296 patients. J Endourol 2008;22:291-294.

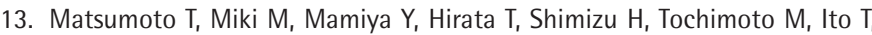
Aika T. Peculiarity of pulsed dye laser lithotriptor and its clinical application. Nihon Hinyokika Gakkai Zasshi 1989;80:1278-1285.

14. Dretler SP. An evaluation of ureteral laser lithotripsy: 225 consecutive patients. J Urol 1990;143:267-272.

15. Ilker $Y$, Ozgür A, Yazici C. Treatment of ureteral stones using Holmium:YAG laser. Int Urol Nephrol 2005;37:31-34.

16. Bagley DH. Expanding role of ureteroscopy and laser lithotripsy for treatment of proximal ureteral and intrarenal calculi. Curr Opin Urol 2002;12:277-280

17. Burak Turna, Oktay Nazli. Ureteroscopy: Indications and outcomes. Turk J Urol 2008;34:423-430.

18. Kassem A, Elfayoumy $H$, Elsaied W, Elgammal M, Bedair A. Laser and pneumatic lithotripsy in the endoscopic management of large ureteric stones: a comparative study. Urol Int 2012;88:311-315.

19. Sözen S, Küpeli B, Tunc L, Senocak C, Alkibay T, Karaoğlan U, Bozkirli I. Manage $\neg$ ment of ureteral stones with pneumatic lithotripsy: report of 500 patients. J En dourol 2003;17:721-724.

20. Aydemir H, Budak S, Hirik E, Kumsar Ş, Çelik O, Adsan Ö. Upper Ureteral Stone Treatment: Effectiveness and Complications of Holmium Laser and Pneumatic Lithotripsy. J Clin Anal Med 2016;7:46-49.

21. Tipu SA, Malik HA, Mohhayuddin N, Sultan G, Hussain M, Hashmi A, Naqvi SA, Rizvi SA. Treatment of ureteric calculi--use of Holmium: YAG laser lithotripsy versus pneu-matic lithoclast. J Park Med Assoc 2007;57:440-443.

22. Razzaghi MR, Razi A, Mazloomfard MM, Golmohammadi Taklimi A, Valipour $R$, Razzaghi Z. Safety and efficacy of pneumatic lithotripters versus holmium laser in management of ureteral calculi: a randomized clinical trial. Urol J 2013;10:762-766

23. Perez Castro E, Osther PJ, Jinga V, Razvi H, Stravodimos KG, Parikh $K_{1}$ Kural AR, de la Rosette JJ; CROES Ureteroscopy Global Study Group. Differences in ureteroscopic stone treatment and outcomes for distal, mid-, proximal, or multiple ureteral locations: the Clinical Research Office of the Endourological Society ureteroscopy global study. Eur Urol 2014;66:102109.

24. Strohmaier WL, Schubert G, Rosenkranz T, Weigl A. Comparison of extracorporeal shock wave lithotripsy and ureteroscopy in the treatment of ureteral calculi: a prospective study. Eur Urol 1999;36:376-379.

25. Tuğcu V, Taşci Al, Ozbek E, Aras B, Verim L, Gürkan L. Does stone dimension affect the effectiveness of ureteroscopic lithotripsy in distal ureteral stones? Int Urol Nephrol 2008;40:269-275.

26. Taş S, Tuğcu V, Mutlu B, Karadağ S, Bitkin A, Yücel M, Taşçi Al. Incidence of ureteral stricture after ureterorenoscopic pneumatic lithotripsy for distal ureteral calculi. Arch Ital Urol Androl 2011;83:141-146.

27. Kuroda $\mathrm{S}$, Ito H, Sakamaki K, Tabei T, Kawahara T, Fujikawa A, Makiyama $K_{\text {, }}$ Yao $M$, Uemura $H$, Matsuzaki J. A new prediction model for operative time of flexible ureteroscopy with lithotripsy for the treatment of renal stones. PLoS One 2018;13:e0192597. 